\title{
When Disaster Strikes Small Islands. The Right of Overseas Territories and Micro-States to Claim International Attention
}

\author{
By Aron V. Mir Haschemi, Bonn / Berlin
}

In the field of humanitarian assistance, the term "forgotten crisis" describes an emergency situation assessed to be in need of humanitarian action, yet lacking important media coverage and public attention.

The fact that local or foreign politicians, international civil servants, humanitarian aid workers or the victims declare a specific situation an emergency does not necessarily sell it to the global information market. Pierre Gassmann, senior policy maker with the International Committee of the Red Cross, was reminded at this dilemma as he accompanied an ICRC delegation to the US-American Cable News Network, CNN, in Atlanta, Georgia ${ }^{1}$. The delegation was trying to convince CNN to cover the Great Lakes Crisis in 1994; the television network refused to cover Rwanda and Burundi as they already had one group of journalists in the politically evolving Republic of South Africa. More than one major news topic from the African continent was not possible under the company's business policy for headline news. Such network news is received all over the world and is likely to attract the attention of the international community. This is known as the "CNN effect".

Forgotten crises of the classical type are found, for example, in Western Sahara - with little population and even less lobbying capacity in the international community - or in the Southern Province of Senegal, Casamance, where civil unrest has been part of everyday life for the past twenty years. There are, however, many other regions or countries which per se seem to be forgotten, and which therefore, when an emergency occurs, start grasping for international attention although they have an even less privileged status than small countries such as Western Sahara.

To give an example: If an emergency occurs in the second smallest African country ${ }^{2}$, São Tomé e Príncipe, how does this small island country make itself heard? Through regional

Pierre Gassmann reported this experience during the IV. Humanitarian Conference at the Charite, Berlin, 29 - 30 November 2002.

2

US Central Intelligence Agency, CIA World Factbook 2004, http://www.cia.gov/cia/publications/ factbook/geos/tp.html (accessed on 30 July 2004): The Democratic Republic of São Tomé and 
integration, it could call on the African Union. At the same time, its former colonial power, Portugal, which granted it independence only in 1975, still has an interest in maintaining its international sphere of influence, of which São Tomé e Príncipe is a part.

Or it could turn to France, which after bringing the former Spanish colony of Equatorial Guinea into the Francophonie Organization, also tried to extend its influence over the former Portuguese possessions in Africa, and thus has a certain degree of interest in São Tomé e Príncipe as well. This small island republic could quite easily obtain European attention for itself through diplomatic channels.

Yet another recourse is Brazil, which - as South America's only lusophone country and a regional power - claims a dominant position within the community of Portuguese-speaking countries.

This short analysis shows that, given the de jure and de facto sovereignty of an independent state, interaction with the international community is available.

That privileged position is also accorded to weak states - even to the micro-states of Africa, as long as they enjoy sovereignty ${ }^{3}$. But what happens to territories which, firstly, do not have sovereignty and, secondly, cannot or do not apply the right of self-determination to gain sovereignty? Territories at war or under occupation usually receive some international attention. This applies to Afghanistan, Iraq, and Chechnya in times of war; the Palestinian territories are covered in the news of most countries of the world; Western Sahara has had UN missions; formerly Portuguese and Indonesian East Timor received help to become independent until recently; and Aceh Province's struggle for autonomy becomes visible to the large media markets every time an act of violence produces victims. The same attention applies to the Special Administrative Regions (SARs) Macao and Hongkong with their

Príncipe: has a total area of 1,001 square kilometres and a population of 181,565 (July 2004 estimation).

Other African countries with a total area of less than 40,000 square kilometres, which could therefore be classified as territorial micro-states as well, are (population in brackets): Burundi $(6,231,221)$; Cape Verde (415,294); Comoros (651,901); Djibouti (466,900); The Gambia $(1,546,848)$; Guinea-Bissau (1,388,363); Equatorial Guinea $(523,051)$; Lesotho $(1,865,040)$; Mauritius $(1,220,480)$; Rwanda $(7,954,013)$; Seychelles $(80,832)$; Swaziland $(1,169,241)$. The Worldbank uses the criteria of a population of less than 3,000,000 to define the group of microstates. For Africa, this would encompass Mauritania $(2,998,563)$; the Republic of Congo $(2,998,040)$; Namibia $(1,954,033)$; Botswana $(1,561,973)$; and Gabon $(1,355,246)$. Both Burundi and Rwanda do not belong to this category. Population estimates as of July 2004, US Central Intelligence Agency, CIA World Factbook 2004, http://www.cia.gov/cia/publications/factbook/, accessed on 30 July 2004. 
internationally assured particular legal autonomy and position within the People's Republic of China.

The situation of Overseas Countries, Possessions and Territories ${ }^{4}$, vestiges of colonial times, is different. These are mainly islands and usually small, and are not considered by the international community to be under occupation. Some are inhabited only by populations who migrated there under colonial rule or afterwards. Most have been possessions of their motherlands since the early days of imperialism and colonialism, and were sometimes later ceded to a legal successor of the original colonial power. They are remote from their metropolitan motherlands, which give them an internationally renowned political framework. Most such Territories are, for diverse reasons, not in a position to claim or are not interested in claiming full sovereignty today, although some could do so under public international law.

Due to their small size or small population, such Territories are not in the international public eye. For example, in 1993, all of the inhabited Overseas Countries and Territories of the member states of the European Union totalled an estimated 876,045 people ${ }^{5}$. For 2004, estimates suggest an overall overseas population of more than $1,200,000^{6}$, plus another 4,300,000 living in ultra-peripheral regions. These are remote areas that are full member territories of the European Union ${ }^{7}$. Although this data suggests that there has been an important population increase, this has not brought much public awareness.

In the following, the term Overseas Territories is meant to comprise all administrational types of remote areas other than land-linked or closely situated ones to the mother land.

5 The distribution was: Greenland 55,100; Mayotte 94,400; New Caledonia 169,900; French Polynesia 199,000; St-Pierre-et-Miquelon 6,390; Wallis-et-Futuna 13,700; Anguilla 9,000; Cayman Islands 30,000; Falkland Islands 2,000; Montserrat 12,000; Pitcairn 55; St-Helena and dependencies 7,000; Turks and Caicos 2,000; British Virgin Islands 13,000; Aruba 71,200; Netherlands Antilles 191,300. Estimated populations in 1992-93 by Eurostat 1994. A total of 876,045 in the Overseas Countries and Territories (OCT) compared to 350 million inhabitants in the EC of the 12 .

6 The CIA World Factbook 2004 includes the following estimates for July 2004: Greenland 56,384; Mayotte 186,026; New Caledonia 213,679; French Polynesia 266,339; St-Pierre et Miquelon 6,995; Wallis et Futuna 15,880; Anguilla 13,008; Bermuda 64,935; Cayman Islands 43,103; Falkland Islands 2,967; Montserrat 9,245 (plus around 6,000 refugees who have not yet returned to the island after the resumption of volcanic activity in July 1995); Pitcairn 46; St. Helena and dependencies 7,415; Turks and Caicos 19,956; British Virgin Islands 22,187; Aruba 71,218 and Netherlands Antilles 218,126. This totals to a population of 1,217,509. The Faroe Islands, constituent part of the Kingdom of Denmark, are not an OCT under European law, but still account for another 46,662 people. CIA World Factbook 2004, cf. fn. 3.

Reunion 766,153; French Guyane 191,309; Guadeloupe 444,515; Martinique 429,510 (estimated population in July 2004, CIA World Factbook 2004, cf. fn. 3); Azores 241,763; Madeira 245,011 (data for 2001, National Statistical Institute of Portugal, www.ine.pt, accessed on 30 July 2004); 
Research on legal, management, political, geographical or interdisciplinary matters has not covered them in depth due to their remoteness. As scholars in the motherlands rarely work on the dependent Territories, there is almost no comparative research. There seems to be no comparative study of different Overseas Territory policies, or of a best practice for small island disaster preparedness.

Due to the lack of academic institutions in the Territories, academics there usually study only few aspects of local life. So it is no surprise that the most extensive scientific discourse relating to the Overseas Territories concerns flora and fauna, and natural science in general. Besides Puerto Rico, with its seven mainly vocationally orientated academies, there are universities in the French Antilles, Reunion, Tahiti and New Caledonia, and in the American Virgin Islands and Guam; there is one higher education institute in Greenland as well. Some Territories in the South Pacific region have access to the services of the University of the South Pacific, USP, with campuses in Fiji, Vanuatu, and the Solomon Islands. USP is based on an international organization. There seems to be no academic institution in the British Overseas Territories, a fact that must be seen in the context of the United Kingdom's semi-private academic system.

\section{Disaster Preparedness}

What happens in Overseas Territories when a disaster occurs? Who is responsible? Is it the populations themselves, the local or regional administrations or the central institutions in Brasilia, Canberra, Copenhagen, London, Paris, Pretoria, Santiago, The Hague or Washington? And, for effective and efficient relief, are there structures of alert and response? If there are structures of emergency management, are these applied to the particularity and remoteness, to the special needs of small non-urbanized populations, like those in many of the Overseas Territories? Do structures of disaster preparedness follow up-to-date managerial methods and do they take into consideration the continuum debate or the Linking Relief, Rehabilitation and Development (LRRD) approach? Do the Overseas Territories or their populations have a legal claim to assistance from their motherlands? Is the central state liable for damages incurred due to bad management or neglected disaster relief?

Canary Islands 1,870,579; Ceuta 76,152 and Melilla 69,184 (data for 2003, oral communication from the Spanish Embassy to Germany). Although the sources offer data for different years, these numbers suggest that there are about 4,334,176 inhabitants in the ultra-peripheral regions (UPR) of the EU. 
Finally, in this context the question must be raised as to whether there is such a concept as partial sovereignty in external affairs. The specific status of the Cook Islands is a good model for studying new paths of participation in the international community that have already been taken. How could maintaining international relations in the geopolitical neighbourhood help Overseas Territories to improve their disaster preparedness?

Jürgen Osterhammel ${ }^{8}$ considers 40 territories as forming the category of post-colonial Overseas Territories. The list can easily be expanded to a total of around 80 territories that should be examined in a study of Overseas Territories, of which about 40 are inhabited and count for the classical metropoles, mainlands and former colonial powers in Europe and the US. The Pacific regional powers Australia and New Zealand and the countries with their at first glance - more original dependencies possess another 40 territories with local populations.

The following list of possible Overseas Territories demonstrates the plurality among these relicts from colonial times:

\begin{tabular}{|c|c|}
\hline \multicolumn{2}{|l|}{ European Union member states: } \\
\hline Ultra-Peripheral Regions (UPRs) : & \\
\hline French Republic & $\begin{array}{l}\text { Départements d'Outre-Mer (DOM) : Guadeloupe et } \\
\text { dépendances (Saint-Martin etc), Martinique, Guyane } \\
\text { française (continental non-insular), La Réunion }\end{array}$ \\
\hline Kingdom of Spain & $\begin{array}{l}\text { Islas Canarias, Ciudad Autónoma de Ceuta (continental } \\
\text { non-insular), Ciudad Autónoma de Melilla (continental } \\
\text { non-insular) }\end{array}$ \\
\hline Portuguese Republic & $\begin{array}{l}\text { regioes autonomas: Região Autonoma Madeira, Região } \\
\text { Autonoma dos Açores }\end{array}$ \\
\hline \multicolumn{2}{|l|}{$\begin{array}{l}\text { Overseas Countries and Territories } \\
(\text { OCTs })^{9} \text { : }\end{array}$} \\
\hline Kingdom of Denmark & $\begin{array}{l}\text { Kallit Nunaat (Greenland; member region of the EC until } \\
\text { 1985) }\end{array}$ \\
\hline French Republic & $\begin{array}{l}\text { Collectivités territoriales : Mayotte, Saint-Pierre et } \\
\text { Miquelon ;Territoires d'Outre-Mer (TOM) : Nouvelles } \\
\text { Calédonie et dépendances, Polynésie française (Ile } \\
\text { Clipperton incluse), Wallis et Futuna, Terres australes et } \\
\text { antarctiques françaises (French claim on Adélie Land in } \\
\text { Antarctica disputed) }\end{array}$ \\
\hline
\end{tabular}
articles $182-188$ (former $131-136 a$ ); list of OCT in Annex II to EC Treaty part IV. See Council Decision 91/482/EC. 


\begin{tabular}{|c|c|}
\hline United Kingdom & $\begin{array}{l}\text { Anguilla, Bermuda, British Antarctic Territory (disputed), } \\
\text { British Indian Ocean Territory, British Virgin Islands, } \\
\text { Cayman Islands, Falkland Islands (claimed by Argentina, } \\
\text { therefore disputed), Montserrat, Pitcairn Islands, Saint } \\
\text { Helena and Dependencies (Tristan da Cunha, Ascension), } \\
\text { South Georgia and South Sandwich Islands (claimed by } \\
\text { Argentina, therefore disputed), Turks and Caicos Islands }\end{array}$ \\
\hline Kingdom of the Netherlands & $\begin{array}{l}\text { Aruba, Netherlands Antilles (Curaçao, Bonaire, Saba, Sint } \\
\text { Maarten, Sint Eustache) }\end{array}$ \\
\hline \multicolumn{2}{|l|}{ European, basically extra EU: } \\
\hline Kingdom of Denmark & Faeroe Islands \\
\hline Republic of Finland & $\begin{array}{l}\text { Åland (autonomy; special relationship with, but part of the } \\
\text { EU) }\end{array}$ \\
\hline Kingdom of Norway & $\begin{array}{l}\text { Svalbard }{ }^{10} \text { (and Bear Island), Dronning Maud Land with } \\
\text { Peter Island (claimed but disputed), Bouvet Island, Jan } \\
\text { Mayen }{ }^{11}\end{array}$ \\
\hline United Kingdom & $\begin{array}{l}\text { Gibraltar (continental non-insular; Gibraltar in fact is } \\
\text { quasi-member territory of the European Communities } \\
\text { under particular arrangement }{ }^{12} \text { ); Channel Islands: } \\
\text { Guernsey, Jersey (including Alderney, Sark etc), Isle of } \\
\text { Man (Crown Dependencies) }\end{array}$ \\
\hline United States of America & $\begin{array}{l}\text { Hawai'i (State of the USA); Puerto Rico; Territories: } \\
\text { American Samoa (including Swains Island and Rose } \\
\text { Island), Guam, the U.S. Virgin Islands, the Commonwealth } \\
\text { of the Northern Mariana Islands; Freely associated States: } \\
\text { the Federated States of Micronesia, the Republic of the } \\
\text { Marshall Islands, the Republic of Palau' }{ }^{13} \text {; Baker Island, } \\
\text { Howland Island, Jarvis Island, Johnston Atoll, Kingman } \\
\text { Reef, Midway Islands, Navassa Island, Palmyra Atoll, } \\
\text { Wake Island; in addition, the status of certain camps of the } \\
\text { armed forces has to be considered (e.g. Guantanamo Bay, } \\
\text { Diego Garcia) }\end{array}$ \\
\hline Republic of South Africa & $\begin{array}{l}\text { Prince Edward Islands (Marion Island and Prince Edward } \\
\text { Island) }\end{array}$ \\
\hline Commonwealth of Australia & $\begin{array}{l}\text { Lord Howe Island and Macquarie Island; Ashmore and } \\
\text { Cartier Islands, Christmas Island, Cocos (Keeling) Islands, } \\
\text { Coral Sea Islands, Heard Island and McDonald Islands, } \\
\text { Norfolk Island, Australian Antarctic Territory (disputed) }\end{array}$ \\
\hline
\end{tabular}

10

Sovereignty of the Kingdom of Norway with the Sysselmannen's governing authority in effect since the Treaty of Spitsbergen in 1920, solemn declaration of incorporation by King Haakon on 25 August 1925.

11

The other Norwegian Overseas Territories are not part of the Kingdom of Norway as of $\S 1$ Constitution of the Kingdom of Norway.

12 Limited Circulation by the Secretary General of the Council of the European Union of 19 April 2000, 7998/00.

13

The freely associated states are UN members. Their defence and, to a certain extent, their external relations are under the responsibility of the US. 


\begin{tabular}{|l|l|}
\hline New Zealand & $\begin{array}{l}\text { Antipodes Islands, Auckland Islands, Bounty Islands, } \\
\text { Campbell Island, Chatham Islands, Kermadec Islands; } \\
\text { Associated States: Cook Islands, Niue, Tokelau; Ross } \\
\text { Dependency (New Zealand Antarctic Territory, disputed) }\end{array}$ \\
\hline Federative Republic of Brazil & $\begin{array}{l}\text { Arquipelago de Fernando de Noronha, Atol das Rocas, Ilha } \\
\text { da Trindade, Ilhas Martin Vaz, Penedos de São Pedro e } \\
\text { São Paulo }\end{array}$ \\
\hline Republic of Chile & $\begin{array}{l}\text { Islas Desventurados (San Félix, San Ambrosia), Islas Juan } \\
\text { Fernández (with Isla Alexander Selkirk and Isla Robinson } \\
\text { Crusoe); Isla de Pascua, Isla Sala y Gomez; claimed } \\
\text { Chilean Antarctic Territory (part of the British Antarctic } \\
\text { Territory, at the same time Argentinian claim, disputed) }\end{array}$ \\
\hline Republic of Colombia & $\begin{array}{l}\text { Isla de Malpelo, Roncador Cay, Serrana Bank, Serranilla } \\
\text { Bank, San Andrés and Providencia (claimed by Honduras) }\end{array}$ \\
\hline Republic of Ecuador & Islas Galápagos \\
\hline United Mexican States & Islas Revilla Gigedo, Guadalupe \\
\hline Argentine Republic & $\begin{array}{l}\text { Tierra del Fuego - Antartida e Islas del Atlantico Sur (the } \\
\text { claimed Argentinian Antarctic Territory is part of the } \\
\text { Chilean and British Antarctic Territory, disputed) }\end{array}$ \\
\hline Republic of Costa Rica & Isla del Coco \\
\hline Republic of Honduras & Islas de la Bahía including Swan Islands \\
\hline Republic of India & $\begin{array}{l}\text { Amongst the seven Union Territories }{ }^{14} \text { : Andaman and } \\
\text { Nicobar Islands, Lakshadweep }\end{array}$ \\
\hline Japan & $\begin{array}{l}\text { Ogasawara-gunto (Bonin Islands), Minami-tori-shima } \\
\text { (Marcus Island), Kazan-retto (Volcano Islands), Daito- } \\
\text { shoto, Okino-tori-shima (Parece Vela); Ryukyu Islands } \\
\text { (Nansei-shoto) and Senkaku-shoto (Senkaku } \\
\text { Islands/Diaoyu Tai, claimed by Taiwan and PR China) }\end{array}$ \\
\hline Republic of Yemen & Socotra \\
\hline People's Republic of China & $\begin{array}{l}\text { Spratly Islands (disputed with Malaysia, Philippines, } \\
\text { Taiwan, Vietnam, possibly Brunei), Paracel Islands } \\
\text { (disputed with Taiwan and Vietnam) }\end{array}$ \\
\hline & \\
\hline
\end{tabular}

This list is based on a concept of Overseas Territories which encompasses more than just non-self-governing territories. Following the Report of the Special Committee on the Situation with regard to the Implementation of the Declaration on the Granting of Independence to Colonial Countries and Peoples for $2001^{15}$, there remain only 16 non-self-

Union Territories are subject to direct governance supervision of the Indian federal government; therefore one cannot expect per se statehood of the Union Territories, which is the case for the States of the Republic of India.

15 United Nations General Assembly: Report of the Special Committee on the Situation with regard to the Implementation of the Declaration on the Granting of Independence to Colonial Countries and Peoples for 2001, A/56/23, New York 2002. The Declaration on the Granting of Independence to Colonial Countries and Peoples, resolution 1514 (XV), was adopted by the United Nations General Assembly on 14 December 1960. 
governing territories today in the category of colonial countries ${ }^{16}$. All of these except for Western Sahara are small islands. This list of 16 territories, however, seems to be comprehensive: the Declaration's purpose is decolonization, which is the recognition of the statehood of each of these territories. Being listed within the group of non-self-governing territories has been shown to pave the way to a country's independence ${ }^{17}$ or veritable autonomy ${ }^{18}$. For the purpose of strengthening a territory's ability to respond to emergency situations, its actual insularity and remoteness must be taken into account.

While the small overall population of all the Overseas Territories together may make it seem easy to neglect disaster preparedness, the horrendous effects of one single disaster are likely to disrupt the very existence of the concerned territory and its people and therefore demand special attention. Their exceptional vulnerability must be accounted for not only by the motherlands, but also by the international community. It is advisable to develop disaster preparedness of Overseas Territories along with the disaster preparedness of small, especially insular micro-states. Both would benefit from cooperation: New contacts could be established between motherlands, their Overseas Territories and insular micro-states. At the same time, Overseas Territories could learn from the experience of insular micro-states most of which are former colonies. Overseas Territories could consequently take advantage of the better position afforded by statehood - even in times when the classical concept of sovereignty seems to be undermined by wars not covered by modern ius ad bellum.

These are American Samoa, Anguilla, Bermuda, British Virgin Islands, Cayman Islands, the Falklands, Gibraltar, Guam, Montserrat, New Caledonia, Pitcairn, Saint Helena, Tokelau, Turks and Caicos Islands, US Virgin Islands, and Western Sahara. An interesting list of non-selfgoverning territories from 1946 to 1999 can be found on the UN internet site: http://www. un.org/Depts/dpi/decolonization/trust2.htm, accessed on 18 May 2004.

17 This was the case for the Comoros Islands which had been put on the list in 1972 and gained independence on 6 July 1975. governing territory. Ever since, New-Caledonia has gained autonomy unknown before under the status of a French Territoire d'Outre-mer. 